\title{
The influence of carbon cost pass through on the link between carbon emission and corporate financial performance in the context of the $\mathrm{EU}$ ETS
}

\author{
Roel Brouwers, Frederiek Schoubben*, Cynthia Van Hulle
}

\begin{abstract}
In this study we examine, within the context of the European Union Emission Trading Scheme (EU ETS), whether firms' ability to pass through carbon costs affects the link between carbon emission and corporate financial performance. Our results, controlling for the endogenous relationship between carbon emission and financial performance and robust to a number of alternative financial performance measures, demonstrate that good carbon emission performance not always pays off. In fact, we find that lower levels of carbon emission is only rewarded if firms are not able to pass on carbon costs to consumers either due to industry characteristics or firm specific carbon efficiency. Our results are in line with the view that as pollution is associated with increasing environmental costs, this negative impact of pollution on financial performance is mitigated for "carbon cost pass through" firms.
\end{abstract}

Keywords: Carbon cost pass through, corporate financial performance (CFP), emission performance (EP), EU ETS, greenhouse gas emission

JEL classification: $614, Q 48$,

Roel Brouwers: KU Leuven, Faculty of Economics and Business, Department of Finance, Korte Nieuwstraat 33, 2000 Antwerp, Belgium; email: roel.brouwers@kuleuven.be

*Frederiek Schoubben: (Corresponding author), KU Leuven, Faculty of Economics and Business, Department of Finance, Korte Nieuwstraat 33, 2000 Antwerp, Belgium; email: frederiek.schoubben@kuleuven.be

Cynthia Van Hulle KU Leuven, Faculty of Economics and Business, Department of Accountancy, Finance and Insurance. Naamsestraat 69, 3000 Leuven, Belgium. Phone: (+)32 (0)16 326734, Fax: (+)32 (0)16 326683, email: cynthia.vanhulle@kuleuven.be

Acknowledgements The authors are grateful to Cédric Bleuez from Carbon Market Data for providing EU ETS data. 


\section{Introduction}

Many studies have analyzed empirically the relationship between corporate carbon pollution and corporate financial performance (CFP). This discussion has been stimulated by the tightening of environmental regulations and the increase in investors' environmental awareness, especially since events such as the Rio Earth Summit in 1992 and the introduction of the Kyoto Protocol in 1997 concerning climate change and the emission of greenhouse gases. This is because the increased concentration of greenhouse gases in the Earth's atmosphere leads to the phenomenon of global warming characterized by climate changes with catastrophic consequences to humanity and ecosystems (Sariannidis et al., 2013). Of the latter, carbon emissions make up approximately $82 \%$ of the total greenhouse gas emissions (Abdallah et al., 2012). According to Ernst and Young (2009), the world has started a transition to a low-carbon economy and this idea is increasingly settling into the mindset of shareholders, investors, consumers and other critical stakeholders. These parties are progressively increasing pressure on managers to invest in carbon reducing facilities.

The environmental economics literature generally suggests that lower corporate carbon pollution, and thus better carbon emission performance (EP) positively affects firms' economic performance. Moreover, these studies show that the emission-financial performance relationship depends on carbon intensity (e.g., Matsumura et al., 2014; Wang et al., 2014), carbon emission mitigation strategies (e.g., Misani et al., 2012; Lannelongue et al., 2015) and the market discipline imposed by investors (e.g., Nishitani and Kokubu, 2012). None of these studies however examine how the emission-financial performance link can be influenced by the (in)ability to pass through environmental costs due to industry specific or firm level characteristics.

In this study, we address this research gap by examining whether firms that are relatively less carbon efficient compared to competitors or are operating in so called "carbon leakage" (i.e., unable to pass on carbon costs to consumers due to global competition) industries would benefit more from improving emission performance. Analogue to studies on the impact of corporate social responsibility (CSR) on financial performance (e.g., GarciaCastro, 2010), we explicitly control for the endogeneity of a firm's carbon emission performance by using a fixed effect instrumental variable (FE-IV) methodology. Endogeneity may occur because a firm that performs well financially can afford to invest more in strategies aimed at emission performance improvement. Moreover, a firm that is efficient at pollution control might also be more efficient in running its general business. 
We conduct our study on a unique sample of 368 listed firms with production facilities regulated under the European Union Emission Trading Scheme (henceforth EU ETS). The EU ETS is a cap-and-trade carbon emission trading system, which can be considered the cornerstone of Europe's climate policy. ${ }^{1}$ Focusing on carbon emission performance in the context of the EU ETS has several advantages. First, the quantity of carbon output is a verifiable, objective (inverse) measure of carbon emission performance that allows us to avoid the complexity of the concept of the more general environmental performance, which has been proven to be a multidimensional construct (Busch and Hoffman, 2011; Endrikat et al., 2014). Although narrower as a concept, carbon emission nevertheless is an important issue that lends itself for a fine grained analysis. Furthermore, verified carbon emissions are published each year on the same date for all installations covered by the EU ETS and can be aggregately measured at firm level (Calel and Dechezleprêtre, 2016). Second, by focusing on all listed firms with facilities covered by the mandatory EU ETS, we avoid any sampleselection bias, compared with voluntary carbon disclosure initiatives. Next, by opting for a panel dataset comprising the two currently completed ETS phases in all participating countries, including all ETS covered industries, we obtain ample cross-sectional variation in carbon pollution. Finally, EU ETS provides us with novel instruments to control for the potential endogeneity of emission performance as measures like regulatory stringency at country level and firm specific variation in emission allowances are strongly related to carbon emissions while arguably exogenous to firm performance. Our sample initially consists of all listed firms with EU ETS installations corresponding to more than a quarter of all installations involved in the system and roughly half of all verified emissions.

Our results show that, overall, EP has a positive impact on CFP. This is in line with most of the literature and the view that pollution is associated with financial risks caused by abatement, litigation, remediation and reputational costs, all of which combined may put considerable pressure on firm performance. However, by making the distinction between firms that are able to pass through carbon costs and firms that are not, we show that the emission-financial performance relationship depends on the industry in which the firm operates and the firm's carbon efficiency within this industry. We demonstrate that superior emission performance is only rewarded financially if firms are unable to pass through carbon related costs to end users and/or consumers due to firm or industry characteristics. Firms that

\footnotetext{
1 The EU ETS, introduced in 2005, was the first and is to date the largest international system for trading greenhouse gas emission allowances, covering almost half of the EU's greenhouse emissions and operating in 31 countries: the 27 EU countries, the three EEA-EFTA states (Iceland, Liechtenstein and Norway) and Croatia (joined in 2013) (European Commission, 2013).
} 
are able to pass on carbon related costs do not show a significant relationship between EP and CFP. This indicates that while pollution is associated with increasing environmental costs, this negative impact of pollution on economic performance is mitigated for these firms. Our results hold after accounting for endogeneity and are robust to a number of alternative performance measures.

With this paper we contribute to the literature in several ways. First, by examining the impact of so called carbon cost pass through, induced by industry specific carbon leakage or firm specific carbon efficiency, on the relationship between emission performance and financial performance, we add to studies like Chan et al. (2013), Jong et al. (2014) and Venmans (2015) that show that the impact of environmental regulation is inherently industry and/or firm specific. The fact that we conduct our tests in the context of the EU ETS contributes to the ongoing debate on the economic as well as environmental consequences of a cap-and-trade system (Clò, 2010; Fisher and Fox, 2012; Schmidt and Heitzig, 2014; Clarkson et al., 2014) and provides additional insight for policy makers on the effectiveness of the EU ETS. Next, our findings that carbon cost pass through and carbon efficiency strongly influence the environmental-financial performance relationship, might partly explain the non-linear (e.g., Trumpp and Guenther, 2017), contrarian (e.g., Wang et al., 2014) or insignificant (e.g., Alvarez, 2012) results found in previous studies on this relationship and shed more light on other inconsistent empirical findings concerning EU ETS (Endrikat et al., 2014; Czerny and Letmathe, 2017). Finally, by using fixed effect instrumental variable (FEIV) regressions, instrumenting for carbon emission performance, we appropriately control for the potential endogenous relationship between EP and CFP. This way our results contribute to the larger debate on the role of endogeneity in the empirical literature linking social/environmental performance with financial performance (Garcia-Castro et al., 2010).

The remainder of the paper is organized as follows. In the next section, we present an overview of the related literature followed by the development of our hypotheses. Next, we provide a description of the data and the research methodology. Empirical results are then presented before the concluding remarks.

\section{Related literature}

Although scholars have used different perspectives in studying the relationship between corporate carbon emission and financial performance, studies can be broadly divided into 
voluntary and mandatory approaches. ${ }^{2}$ The fundamental distinction between both lies in polluters being subjected to either implicit costs imposed by stakeholders in a voluntary context or explicit costs imposed by legislators in the case of a mandatory program (Wahba, 2008).

Within the voluntary context, some studies use data from the Carbon Disclosure Project (henceforth CDP) ${ }^{3}$ or rely on diverse sources such as sustainability reports or CSR reports from company websites or information from specialized organizations. Matsumura et al. (2014) investigate the relationship between carbon emissions and firm value for S\&P 500 firms disclosing their carbon emissions to the CDP over the period 2006-2008. They find a negative relationship between carbon emission levels and firm value, contingent upon managers' decisions to disclose this non-financial information in the first place. Similarly using Newsweek's green rankings data for 2009, Aggarwal and Dow (2012) find for a subsample of listed US firms a negative relationship between market valuation measured as Tobin's Q and carbon emissions. Furthermore, Delmas et al. (2015) report a negative relationship between Tobin's Q and greenhouse gas emissions for their sample of US companies over the period 2004-2008. However in terms of the (accounting) return on assets, the relationship is positive, implying that policies that reduce emissions relate to a lower return. Delmas et al. (2015) interpret the latter finding as the short run impact of emission abatement policy and the negative relationship with Tobin's Q as its long run effect. They suggest that this negative short run effect may help to explain the limited adoption of proactive abatement strategies reported for example in Blass et al. (2013). In an earlier study, Busch and Hofmann (2011) use data from a specialized organization to study the link between carbon emission and financial measures including Tobin's Q, return on assets and return on equity. They use a subset of firms from the Dow Jones Global Index and their data cover the fiscal year 2006. Likewise many other studies, Busch and Hoffmann (2011) report a significant negative relation between carbon emission intensity and Tobin's Q. However, such significant effect for the accounting measures return on assets and return on equity is absent. Similarly, Gallego-Alvarez et al. (2014) assemble CDP-data over the period 2006-2009 for an

\footnotetext{
${ }^{2}$ Busch and Hoffmann (2011) point out that carbon performance comprises two important aspects, viz emissions (or the output view) and carbon management strategies (or the process view). As information on the latter is limited, the vast majority of the literature concerns emissions. As our paper belongs to this latter strand, we focus in our overview of related literature on the output view.

3 The CDP is a United Kingdom's based not-for-profit-organization, formed in 2000 as a United Nations initiative. Its mission is to gather and disseminate climate change information in an effort to create a unified response against global warming (Carbon Disclosure Project, 2013). See e.g. Matisoff et al. (2013) for a more detailed discussion.
} 
international sample of firms and find that the relationship between emissions and financial performance is not always positive. However, they report that in times of economic crisis, the synergy between environmental and financial performance becomes higher. Alvarez (2012) on the other hand, never finds a systematic significant link between carbon emissions and accounting measures of firm performance using an international sample over the period 20062010. Finally, Trumpp and Guenther (2017) show that the relationship between carbon emissions and firm performance is not linear and does not necessarily apply to all industries and performance measures, for their international sample based on CDP data from 2008 to 2012. They find a U-shaped relationship between their inverse carbon emission measure and stock market performance that is most apparent for manufacturing firms.

With the introduction of mandatory greenhouse gas (GHG) disclosure programs around the world, more researchers were able to study the relationship between GHG emissions and firm performance. Nishitani and Kokubu (2012) analyze the effect of GHG emission reduction on Tobin's Q for a sample of Japanese manufacturing firms over the period 20062008. Their results demonstrate that firms' reduction of GHG emissions increases firm value mainly when market discipline imposed by stockholders/investors is strong. Similarly, Fujii et al. (2013) find for a Japanese sample over the period 2006-2008 a positive relationship between emission performance and accounting measures of financial performance. By contrast, using listed Australian companies, Wang et al. (2014) find a positive relationship between carbon pollution and Tobin's Q. They claim however, that this result is mainly due to the dominance of the mining industry in the Australian economy. Finally, in the context of the European Union's emission trading scheme (EU ETS), Jong et al. (2014) and Clarkson et al. (2014) examine empirically the relation between firms' environmental performance and firm value. The first study conducts an event study on the April 2006 carbon price drop. The results indicate that firms' carbon intensity levels and allowance holdings were, respectively, negatively and positively related to firms' stock prices. The authors conclude that firms with lower measures of carbon intensity and larger long positions in carbon allowances are considered more carbon efficient which could lead to competitive advantages. Clarkson et al. (2014) investigate the value relevance of emission allowances under the ETS and measure the firm's pollution level as its shortage in emission allowances. The most striking result of this study is the negative relationship between firm values and carbon emission shortfalls. In a related study, Lannelongue et al. (2015) claim that not solely changes in emission but rather the entire environmental management productivity has to be taken into account when 
exploring the relationship between environmental performance and corporate performance. Using a sample of Spanish production firms covered by EU ETS, they show that only firms with declining emissions due to increased environmental efforts experience positive financial effects. Similarly, Czerny and Letmathe (2017) combine verified emission data from EU ETS with survey data to explore the relationship between environmental and economic performance. They find that not so much the emission reduction induced by emission trading but rather by the environmental strategy focus had a significant positive effect on the economic performance of the carbon-intensive companies.

Generally, most studies demonstrate that carbon $^{4,5}$ emission performance is positively related to firms' financial performance, especially for market value based measures and somewhat less for accounting based measures. Furthermore, this link is affected by firms' carbon intensity (e.g., Matsumura et al.,2014; Wang et al., 2014), emission mitigation strategies (e.g. Lannelongue et al., 2015) and the market discipline imposed by investors (e.g., Nishitani and Kokubu, 2012). None of these studies however, addresses the impact of industry or firm characteristics concerning carbon pass through costing on the emissionfinancial performance relationship.

\section{Hypotheses}

Our first hypothesis follows previous research concerning the effects of carbon emission performance on financial performance. Busch and Hoffmann (2011) develop a theoretical framework to explain the positive relationship between emission performance and financial performance that is usually found in empirical research. They base their logic on operational efficiency and stakeholder pressure arguments. The efficiency argument posits that operational cost savings can be realized by exploiting ecological efficiencies and a better use

\footnotetext{
${ }^{4}$ Also for pollution other than CO2, comparable results are found. For example, Hart and Ahuja (1996) use Toxics Release Inventory (TRI) data and find a negative impact of pollution on several accounting measures of economic performance. King and Lenox (2001) us similar data but further differentiate between pollution performance and divestiture of operations and provide evidence of a positive association between environmental performance and Tobin's Q. Similarly, Konar and Cohen (2001) find that poor environmental performance, as measured by TRI emissions and environmental lawsuits, is related with lower Tobin's Q values for S\&P 500 firms. Cordeiro and Sarkis (1997) examine the link between TRI data and security analyst earnings forecasts as an alternative proxy for firm performance. They find a significant, negative relationship between the level of TRI emissions and industry analyst performance forecasts. Alternatively, Connors and Silva-Gao (2008) explore the "does it pay to be green" question by focusing on the effects of TRI pollution performance on firm-specific risk. The authors find that enhanced environmental performance reduces the cost of equity capital.

${ }^{5}$ Another proxy that has received some attention within the literature involves the emission of Sulphur dioxide (SO2). These SO2 emissions are subject to the first emission cap-and-trade system introduced in the US. Hughes (2000) uses SO2 emissions to examine the value relevance of future environmental liabilities of utility companies. This study reports that, on average, exposure to unbooked environmental liabilities decreased the mean 1990 share price of electric utility companies by 16.3 percent.
} 
of raw materials and energy (e.g. Porter and van der Linde, 1995, Shrivastava, 1995). ${ }^{6}$ Instrumental stakeholder theory posits that effective management of relationships with key stakeholders contribute to marketplace success and hence financial performance (e.g. Donaldson and Preston, 1995; Ambec and Lanoie, 2008; Delmas et al., 2015). It has in multiple ways been linked to climate friendly practices in relation to economic performance. First, good climate performance has a positive impact on a firm's reputation. According to Barth and McNichols (1994) and Hart and Ahuja (1996), the firm's reputation is affected by its environmental profile. Next, Hughes and Reynolds (2001) argue that good environmental performance reduces the cost of complying with climate policy. The greater the firm's ability to mitigate these environmental costs, the more likely investors will increase their estimates of firm value. In fact, Doh et al. (2010) and Delmas et al. (2013) among others, argue that capital markets devalue more carbon-intensive firms. Finally, there are also indirect regulatory costs that can drive the link between EP and CFP. Chapple et al. (2013) argue that good environmental performance avoids substantial financial risks caused by direct costs and indirect costs such as increased regulatory intervention, abatement expenses, and reputational impact. ${ }^{7}$ Overall, in light of previous findings, and firms' increasing exposure to climatechange risks, we propose the following hypothesis for our sample of EU ETS firms:

\section{Hypothesis 1: Carbon emission performance is positively associated with CFP}

Changing marginal costs of pollution as well as stakeholder pressure under the form of regulatory costs are of particular interest in the context of EU ETS. From the beginning, the ETS has generated some controversy as to whether or not companies where actually bearing the cost of compliance. On the one hand, the system provided firms with free allowances. This free allocation of allowances was considered by policy makers as an appropriate measure to minimize adverse impacts on energy-intensive industries subject to the EU ETS (AlexeevaTalebi, 2011). However, studies have revealed that some industrial sectors have even benefited from the ETS in the form of so called windfall profits (Sijm et al., 2006; Oberndorfer, 2009; Venmans, 2015). Economic theory suggests that free allocation is

\footnotetext{
${ }^{6}$ Usually a positive relation between accounting measures of financial performance and emission performance is interpreted as evidence in favor of this argument (e.g. Busch and Hoffmann, 2011; Delmas et al., 2015).

${ }^{7}$ A positive relationship between market based measures and financial performance and emission performance is considered to reflect expectations of stakeholders concerning future effects of the firm's operational ecological policies and future external conditions favoring carbon efficient firms (e.g. Busch and Hoffmann, 2011; Delmas et al., 2015).
} 
appropriate to address competitiveness concerns only if firms are not able to pass through environmental costs to consumers. If firms are able to pass through costs to the consumers, they will do so (Alexeeva-Talebi, 2011). Firms can either use allowances to cover the emissions resulting from the production of their installations or sell them to other firms that need additional allowances. Hence, using allowances represents an opportunity cost, regardless of whether the allowances are allocated for free or purchased at an auction or market (Sijm et al., 2006).

On the other hand, firms that were actually affected by the cap-and-trade system, either when buying allowances to match extra emissions or by abatement investments in order to reduce emissions, were sometimes also able to pass through these costs to end users. This is mainly due to the fact that firms in some industries (e.g., utilities) don't have to compete with firms around the world that do not have to comply with EU ETS. Different studies report on this pass through of pollution costs to customers (e.g., Lise et al., 2010; Alexeeva-Talebi, 2011). Hence, while pollution is associated with increasing environmental costs, firms able to pass through these costs due to industry characteristics are at an advantage as they are less hit financially by the ETS. Therefore, one would expect a less strong relationship between carbon emissions and measures of financial performance for these types of firms. Formulated in line with hypothesis 1 , we propose the following hypothesis:

Hypothesis 2: Firms from industries where carbon related costs cannot be passed through will have a stronger positive relationship between carbon emission performance and CFP

Even in industries where carbon cost pass through is possible, not all firms will be equally able to engage in this practice. Firms with high carbon emission levels and energy-intensive operations relative to direct competitors are likely confronted with regulatory costs resulting from heavy carbon pollution (Clarkson et al., 2014). Clarkson et al. (2014) show that for firms that are more carbon-intensive than their peers, the future profits are pressed downward by the (anticipated) compliance costs. In a competitive environment, these carbon-intensive firms likely are unable to recuperate these increased costs and hence face higher carbon liabilities compared to their more carbon efficient peers. Analogue to Clarkson et al. (2014), we expect therefore that as carbon inefficient firms are unable to avoid bearing extra environmental costs, emission performance becomes more financially relevant for these firms, leading to the following hypothesis: 
Hypothesis 3: Firms that are less carbon efficient compared to industry peers will have a stronger positive relationship between carbon emission performance and CFP

\section{Research Methodology and variables description}

As the relationship between emission performance and corporate financial performance is likely endogenous, causing it to be overstated, we use a fixed effect instrumental variable (FE-IV) methodology to test our hypotheses. Specifically, it may be that firms enhancing their emission performance are simply of higher quality and deliver better emission performance, regardless of whether they choose to act in an environmentally responsible way. In this case, the coefficient on the emission performance variable might reveal a value-add from the "green" engagement, when indeed there is no true effect. To address this endogeneity concern, we examine the relation between emission and firm performance using a two-stage instrumental variable (2SLS) approach. This approach is not uncommon in comparable studies on the impact of corporate social responsibility on corporate performance that suffers from a similar simultaneity biases (Garcia-Castro et al., 2010; Schreck, 2011). With a 2SLS approach, the first stage estimates a predicted value of emission performance ( $\widehat{E P})$, using instrumental variables while the second stage then uses this predicted value as the explanatory variable for corporate financial performance:

$$
E\left(\operatorname{Perf}_{j}\right)=f\left(\widehat{E P}_{j}, \text { control variables }\right)
$$

\section{Corporate financial performance}

The dependent variable for our analyses is corporate financial performance $\left(\operatorname{Per} f_{j}\right)$. In line with studies like Garcia-Castro et al. (2010), Trumpp and Guenther (2017), we use market based as well as accounting based alternatives respectively, in order to enhance the validity of our findings. More specifically, we use Tobin's Q, return on assets (ROA) and return on equity (ROE). ${ }^{8}$ Consistent with previous studies, we use the market-to-book value ratio as a proxy for Tobin's Q. ROA is calculated as operating income over total assets while ROE is the ratio of net income over total book value of equity. All performance measures are adjusted

\footnotetext{
${ }^{8}$ Delmas et al. (2015) argue that Tobin's Q captures the expected long run effects on profitability while the accounting measures capture the impact in the shorter term.
} 
for industry and year effects by subtracting the yearly (2 digit SIC) industry median from the individual firms' respective financial performance values.

\section{Emission performance}

We use the industry and year adjusted carbon intensity to proxy for carbon emission performance $\left(E P_{j}\right)$, in line with studies like Aggarwal and Dow (2012), Matsumura et al. (2014) and Saka and Oshika (2014). The industry-adjusted carbon intensity is measured as verified emissions (from the EU ETS) over a certain year divided by sales, minus the corresponding industry median of this carbon intensity. The firm's industrial affiliation is assessed on the 2 digit SIC code ${ }^{9}$. Note that carbon intensity is an inverse measure of carbon emission performance (EP) as the emission performance increases as our measure of EP decreases.

\section{Control variables}

We control for several variables that are systematically shown to be related to firm value. We control for firm size (Size) calculated as the logarithm of total assets, sales growth (Growth) calculated as the percentage change in sales, leverage calculated by debt to equity and capital intensity (CapInt) calculated as capital expenditures divided by total assets. Finally, we control for firm-fixed effects and year effects. Data on control variables are obtained from Worldscope.

\section{Carbon cost pass through}

In order to measure the (in)ability of a firm to pass through carbon costs to end users and/or customers, we use an industry as well as a firm specific indicator. The industry classification is similar to Jong et al. (2014) and is based on information provided in three Commission decisions (European Commission, 2010; 2011; 2012). These decisions include lists of product category descriptions which are deemed to be exposed to carbon leakage and therefore not eligible for carbon cost pass through as firms within these industries compete with firms around the world that do not have to comply with EU ETS. The commission's assessment is

\footnotetext{
${ }^{9}$ We prefer SIC codes over the European NACE Rev.2-codes. First, SIC codes are commonly used in academic research. Second, according to NACE Rev.2, 25\% of our sample belongs to categories 6420 "Activities of holding companies or 7010 "Activities of head office". We alternatively used the alternative Fama-French industry classification ( 30 industries) and the results remain qualitatively the same.
} 
based on the industries' net regulatory cost increase, which is the part of cost increase caused by the ETS that firms cannot pass through to consumers (Clò, 2010). The net cost increase is based on carbon intensity and trade intensity. The former is calculated using the direct and indirect ETS costs relative to the gross value added of an industry. Trade intensity is defined as the ratio of the total value of imports/exports with countries outside the EU ETS region over the total market size in this region (EU Commission, 2009, p. 24). For an industry to be characterized by the Commission as unable to pass through carbon costs, certain thresholds of either carbon intensity, trade intensity or both have to be surpassed. We thus define pass through and no pass through subsamples by matching the trade description of the firms in our sample with the European Commission's lists of no pass through industry descriptions. Notice that this labeling is more detailed than the 2 digit SIC classification used when calculating industry adjustments for several variables. As a result both pass through and no pass through firms can be in the same 2 digit SIC industry.

Alternatively, we also determine a firm specific ability to pass through pollution costs regardless of the industry description. Following Clarkson et al. (2014), we argue that the firms' ability to pass through pollution costs can be related to the firms' carbon efficiency relative to peers. Given the consumer demand elasticity, high polluters in their industries will not be able to fully pass on environmental costs to their product prices. As a consequence, high polluting firms have a competitive disadvantage compared to their better environmentally performing industry rivals. We therefore split our sample into high and low carbon efficiency based on whether a firm's carbon intensity is above or below the (2 digit SIC) industry median.

\section{Instrumental variables (IV)}

The condition for a good instrumental variable is that the instrument correlates with the potentially endogenous explanatory variable, but does not correlate with the dependent variable other than through its relationship with the explanatory variable. However, it is difficult to identify a proper instrument as instrument relevance and exogeneity often work against one another (Semadeni et al., 2014). For this reason, most empirical studies use either weak instruments, which are exogenous but have a low correlation with the endogenous explanatory variable, or semi-endogenous instruments, which are partially endogenous but have a high correlation with the endogenous variable (Larcker and Rusticus, 2010). Relying on weak instruments may result in a bias that is even larger than the original endogeneity bias. 
Even if the instruments are perfectly exogenous, the low correlation with the endogenous variable can increase asymptotic standard errors and reduce the power of the tests (Wang, 2015). Therefore, we use semi-endogenous instruments. According to Larcker and Rusticus (2010), the instrumental variable estimator should be preferred if (1) the correlation between the chosen instrument and the endogenous variable is high and (2) a theoretical or practical argument can be made regarding why the instrument is considerably more exogenous than the endogenous regressor. Since we analyze panel data over different countries, we include two firm-level and one country-level instrument. As the first firm-level instrument, we use the absolute carbon intensity (L.Intenstity), lagged one year. Past absolute carbon intensity can have a simultaneity relation with past firm performance, which may, in turn, correlate with current firm performance. The endogeneity of this instrument in relation with current firm performance depends in this case on the autocorrelation in firm performance but prior literature finds that this autocorrelation is weak (Little, 1962; Rayner and Little, 1966, in Renders et al., 2010). Also in our dataset, the autocorrelations are below 32 per cent. ${ }^{10}$ As the second firm-level instrument, we use the yearly percentage change in the emissions-to-cap ratio $(\triangle E T C)$. The emissions-to-cap ratio is calculated as the difference between verified and allocated emissions divided by allocated emissions. ${ }^{11} 12$ This instrument meets the above mentioned conditions. First, it is negatively related to a firms' carbon emission performance as a positive change in the emissions-to-cap ratio indicates an increase of carbon emissions and hence, worse emission performance. Second, it should not be correlated with CFP as, due to low carbon prices ${ }^{13}$, the impact of the change in the emissions-to-cap ratio on a firms' value, is negligible. As noted by Veith et al. (2009), emission certificates have a significant impact on firms' economic performance only as long as it seriously impacts earnings, which was clearly not the case during the first and second ETS phases. This reasoning is also in line with Grubb et al. (2009), who argue that emission certificates are not a critical factor affecting profitability, when carbon prices are too low.

As the country-level instrument, we use the countries' environmental stringency (Stringency). We control for the stringency of the regulatory environment in which the firm

\footnotetext{
${ }^{10}$ Moreover as our performance measures are industry corrected while the lagged intensity is absolute, the strength of this instrument is further increased.

${ }^{11}$ A positive ETC reflects a short position in allowances while a negative number reflects a long position.

${ }^{12} \mathrm{We}$ prefer the change in ETC over the absolute level of ETC as the latter provides less convincing HansenSargan tests.

${ }^{13}$ The carbon price is largely determined by the current and anticipated scarcity of emission certificates. The first two ETS phases have been plagued by aggregate overallocation of emission certificates, resulting in low carbon prices (Venmans, 2012).
} 
operates by considering the NAPs (National Allocation Plan) issued by every country with installations covered by the ETS. The NAPs and the stringency of these allocations plans have been thoroughly analyzed in different studies (e.g., Gilbert et al., 2004; Grubb et al., 2005; Betz et al, 2006; ). Following these studies, we define stringent NAPs for the first ETS phase as plans that have allocated fewer allowances than national Kyoto targets (Gilbert et al., 2004; Grubb et al., 2005). For the second phase NAPs that have allocated fewer allowances than the 2005 verified emissions are considered to be stringent (Betz et al., 2006). Table 1 reports the stringency level for the ETS covered countries. Only three countries (i.e., Germany, Hungary and UK) can be classified as having stringent ETS requirements for the first two phases of the system.

$$
<<<\text { Insert Table } 1 \text { here }>>>
$$

As most of our listed companies have EU ETS covered installations in several countries, we have to take into account differences in stringency. For each firm, we create a measure of the average regulatory stringency it faces by calculating the weighted-average of the regulatory stringency for all the countries in which the firm operates. ${ }^{14}$ This measure of average stringency can be considered to be a valid instrument as it should be correlated with the carbon emissions performance of firms. There are different studies indicating that environmental regulation stimulates environmental innovation (e.g., Kneller and Manderson, 2012; Kesidou and Demirel, 2012). On the other hand, the instrument should also be exogenous because firm performance is not directly related to countries' environmental regulation. All FE-IV estimations in this paper pass the tests for weak instruments (Stock and Yogo, 2004), the Hausman (1978) test for endogeneity, and the Hansen-Sargan overidentifying restrictions test. An overview of all the variables used in this study can be found in the Appendix.

\section{Sample description and univariate statistics}

Our study draws on a sample of 368 European listed firms with installations covered by the EU Emissions Trading scheme over the period 2005-2012, spanning the entire first and

\footnotetext{
${ }^{14}$ We divide the verified emissions of each firm's installation by the firm's total verified emissions to measure the relative size of the installation with respect to the firm's other installations. Example: firm A has 3 installations; installation 1 with 10000 verified emissions, installation 2 with 20000 verified emissions and installation 3 with 30000 verified emissions. Firm A's number of total emissions equals 60000 . Installation 1 and 2 are located in countries with a stringent environmental policy. Therefore the measure of regulation of firm A equals $0.5(10000 / 60000+20000 / 60000)$.
} 
second ETS phases. Since the number of time series observations is not always the same for each firm, the data form an unbalanced panel data set of 2593 firm-year observations. We matched the emissions data from the CITL, provided by the Carbon Market Data database ${ }^{15}$ to financial data from Thomson Reuters DataStream. Unfortunately, the CITL reports ownership of facilities inconsistently, making necessary a manually matching of installations to firms. The data matching procedure is accomplished in two steps following a matching procedure similar to Calel and Dechezleprêtre (2016).

First, we select all listed firms with installations covered by the ETS. We start from a list of all European listed firms ${ }^{16}$. Next we match this list with the ETS installation database provided by Carbon Market Data. A computer algorithm is used to identify potential matches based on the similarity of firm name, installation name and account holder name ${ }^{17}$. In a next step, we select the actual matches from the computer-generated proposed matches. Using this methodology, we are able to select all 368 listed firms from 25 countries that have installations covered by the ETS (see table 2).

$$
<<<\text { Insert Table } 2 \text { here }>>>
$$

After selecting all listed ETS regulated firms, we identify all the installations owned by these firms to aggregate emissions at the firm level. To select all the installations owned by these 368 listed companies in our set, we link installations' names and account holders' names to companies by company name. Next we select a list of subsidiaries of the initial listed firms with ETS obligations ${ }^{18}$. Finally, we check the e-mail addresses of installation's contact persons. In total, we manage to match 3533 installations with our set of listed firms. As there are 12998 installations covered by the ETS, our dataset represents $27.2 \%$ of the total number of installations, covering approximately $50 \%$ of total verified emissions in 2012 . Table 2 presents the regional distribution of ETS regulated listed firms and installations in our dataset, compared to the distribution of all installations covered by the ETS. The countries that are most represented in our sample are the five largest European economies; Germany, the United Kingdom, France, Italy and Spain. These countries account for $53.53 \%$ of listed companies

\footnotetext{
${ }^{15}$ Carbon Market Data is a carbon market research company and data vendor. The Carbon Market Data database is based on information publicized by the CITL (Community Information Transaction Log) and contains all the information on verified and allocated emissions of 12998 installations in the ETS. The Carbon Market Data database provides information about the installation (name, address, contact person) and the account holder of the installation.

16 This information was obtained from the Amadeus database.

${ }^{17}$ The account holder is the operator who manages the installation's carbon allowances.

18 This list is obtained from Amadeus. Only majority owned subsidiaries, located in countries covered by the ETS and without a link to the parent company by name, are included.
} 
and $57.79 \%$ of sample installations. As in these five countries $48.77 \%$ of all ETS installations are located, our dataset corresponds well with the population of firms affected by the ETS.

Table 3 provides some univariate statistics of the variables for the full sample as well as subsamples based on carbon pass through costing. Incidentally, firms in industries where carbon costs can be passed on to end users seem more valuable and profitable as our three performance variables are always higher. Pass through firms also have significantly better emission performance as EP can be interpreted as an inverse measure of emission performance. Notice that for the full sample, the median value for EP is obviously 0 since it is measured relative to the ( 2 digit sic) industry. Also the instruments for emission performance seem significantly worse for no pass through firms as they have a higher carbon intensity and operate in a less stringent environment. However, as there is on average a slightly more negative average change in the emissions to cap ratio for no pass through firms, there seems to be somewhat more emission reduction over the sample period for the latter group.

$$
<<<\text { Insert Table } 3 \text { here }>>>
$$

Table 4 reports the correlation matrix for the continuous variables included in the regression analysis. We distinguish between firms able to pass through pollution costs (upper right side) and firms not able to pass through pollution costs (lower left side) using the industry specific measure. Although EP is negatively correlated with the performance measures for both the pass-through and no pass-through sample, the correlation coefficient is clearly higher and more significant for the no pass through sample. This result is in line with both hypothesis 1 and 2 which state that emission performance is positively associated with CFP and that this association is stronger for firms not able to pass through pollution costs. The correlation matrix also supports the validity of the instruments. As expected, we find strong positive correlations between EP on the one hand and L.Intensity and $\triangle E T C$ on the other. Further, Stringency is negatively correlated with EP while there is a low association with the performance measures.

Remarkable are the highly negative coefficients between the intensity measures and Size. These results can be explained by the fact that larger firms have a larger capacity to implement abatement activities due to their stronger economic power to carry out the necessary investments (Stanwick and Stanwick, 1998). By contrast, a firm's small size can constitute a barrier if small firms lack human, technical and financial resources (Del Río, 
2009). The positive effect of size on abatement activities is, amongst others, found by Rennings et al. (2006) and Frondel et al. (2006). Rennings et al. (2006) acknowledge a positive influence of size on environmental process innovations and Frondel et al. (2006) show a positive influence of size in both cleaner production and end of pipe technologies.

$<<<$ Insert Table 4 here $>>>$ 


\section{Multivariate results}

Since, as already mentioned earlier in this paper, there are arguments to justify a possible endogeneity and reverse causality of the relationship between EP and CFP, we apply the Hausman test (Hausman, 1978) for endogeneity to empirically test its existence. As shown in Table 5, the results for this test are statistically significant. We therefore accept the null hypothesis, which corroborates the presence of endogeneity and justifies the use of two-stage instrumental variable (IV) regressions.

$$
<<<\text { Insert Table } 5 \text { here }>>>
$$

In Table 6, the results of the first-stage instrumental variables (IV) estimation are shown. These results allow for the prediction of a firms' emission performance. Regarding the instrumental variables, the results indicate that the instruments are properly chosen. First, both lagged intensity, the change in the emissions-to-cap ratio and stringency are significantly related with emission performance and their estimator signs follow our expectations. Second, the partial $\mathrm{R}^{2}$ of the instruments are high, ranging from 45.69 to 49.33 percent. Third, the Fstatistic of the regressions are highly significant and are much larger than the necessary critical values proposed by Stock and Yogo (2004).

$$
<<<\text { Insert Table } 6 \text { here }>>>
$$

Table 7 shows the results of the second-stage instrumental variables (FE-IV) estimation. In this stage, the impact of EP on the CFP of firms (TOBIN's Q, ROA, ROE) is analyzed for the full sample and for the subsamples based on the industry classification that indicates whether or not firms are able to pass through carbon costs. The Hansen-Sargan tests show that the instruments are valid; the null hypothesis of valid instruments cannot be rejected. Overall, the full sample results demonstrate that emission performance (inversely measured by EP) is positively associated with CFP, although only significant with Tobin's Q as the dependent variable. The fact that we only find a distinctively positive relationship between emission performance and CFP for the market-based performance measure is in line with most studies (e.g., Delmas et al., 2015). The split sample results, however, offer a more nuanced image while providing more insight in the impact of carbon cost pass through on the EP-CFP relationship. While the link between emission performance and CFP is always strong and significantly positive for no pass through firms, irrespective of the performance measure used, the impact of EP on CFP is not significant for pass through firms. This distinctively different 
relationship depending on industry characteristics may contribute to our understanding of the conflicting empirical findings in previous studies (Endrikat et al., 2014). Carbon emission performance does have a positive relationship with corporate financial performance, in line with our first hypothesis, but not across all industries due to differences in the ability to pass through carbon costs. To allow comparison of the EP coefficients between subsamples, we perform a Wald test (Weesie, 1999) with the null hypothesis that the coefficients on emission performance are equal across the subsets of firms that are able and those that are not able to pass through carbon costs, all else being equal. The Wald test, reported at the bottom of Table 7, indicates that the difference between the coefficient of EP for the pass through and no pass through subsamples is significant at the 5\% level for ROE and ROA, and at the $10 \%$ level for Tobin's Q. ${ }^{19}$

The results from Table 7 are in line with our second hypothesis and consistent with the initial view that the positive association between emission and economic performance is weaker for firms that are able to pass through pollution costs. For these firms, the emission performance is of a lesser importance as the negative impact of pollution on economic performance is smaller. It also shows, in line with earlier studies (e.g., Chan et al.,2013; Jong et al., 2014 and Venmans, 2015), that the impact of a cap-and-trade system like EU ETS varies considerably across industries. Our results of the no pass through subsamples are not only statistically significant but also economically meaningful. A one standard deviation change in the EP measure (i.e., 1.905), all other things being equal, leads to a change in Tobin's Q, ROA and ROE of $13.23 \%, 45.12 \%$ and $60.78 \%$ over the respective mean values. ${ }^{20}$ To control for the fact that the standard deviation of these financial performance measures is far from equal, we also calculate the impact of a one standard deviation change in EP as a percentage of the standard deviation of either Tobin's Q (0.525), ROA (5.748) or ROE (16.935). Interestingly, this yields a very similar economic impact of EP on the financial performance measures of $33.02 \%, 37.88 \%$ and $33.48 \%$ respectively. As long as firms are unable to pass through the costs of pollution, both market-based and accounting based performance measures seem equally affected by carbon emission performance.

$$
<<<\text { Insert Table } 7 \text { here }>>>
$$

\footnotetext{
${ }^{19}$ In an alternative test, not reported, we estimate a full interaction (FE-IV) model where al variables are interacted with the industry dummy that indicates no pass through ability due to carbon leakage. Equivalent to the Wald test statistic in Table 7, the interaction between this dummy and emission performance is significant for the Tobin's Q, ROA and ROE models. This further confirms the difference in impact of emission performance depending on pass through capacity.

${ }^{20}$ Due to the insignificance of most of the other EP coefficients in Table 7, we do not report the measures of economic significance for the full sample and the pass through sub samples.
} 
In order to test the third hypothesis, we use firm specific carbon efficiency to separate firms based on pass through costing. As firms with higher carbon intensity compared to competitors are less able to pass on additional carbon costs to customers, they should face a stronger relationship between their emission and economic performance (Clarkson et al, 2014). Table 8 reports on the results using the firm specific measure of carbon cost pass through to split the full sample. Similar to the results of Table 7, and in line with the third hypothesis, we find a significant relationship between EP and CFP only for firms that are not able to pass through carbon costs. This implies that also within a certain industry, firms do not benefit from a further improvement of emission performance once they are already very carbon efficient. ${ }^{21}$ Again, the Wald test at the bottom of Table 8 confirms that the difference between EP coefficients across subsamples is statistically significant. When we address the economic relevance of the significant EP-coefficients in Table 8, an interesting result emerges. A one standard deviation increase in the EP measure (1.360) in the no pass through subsample has a much more important economic impact compared to the no pass through subsample of Table 7. For Tobin's Q, the impact increases to $40.93 \%$ of its standard deviation (0.505) while for the accounting measures the economic impact is even more pronounced with a $103.89 \%$ and $97.15 \%$ change relative to the standard deviation of ROA (5.773) and ROE (18.240) respectively.

Results from Table 8 support the arguments in Czerny and Letmathe (2017) that firms with an already advanced technology at the beginning of the EU ETS (i.e., highly carbon efficient) are expected to reluctantly engage in further emission abatement. This explains why variation in EP among carbon efficient firms is unrelated to these firm's financial performance. On the other hand, similar to the findings of Clarkson et al. (2014), carbon inefficient firms that are not able to avoid environmental costs, would benefit financially from carbon emission improvement. Therefore, mainly firms with strong carbon liabilities are likely to see immediate results from improvement in the form of an increase in market value or profitability. Overall, our results are in line with the view that as pollution is associated with increasing environmental costs, this negative impact of pollution on economic performance is mitigated for pass through firms reducing the incentive for further carbon emission performance improvement.

\footnotetext{
${ }^{21}$ In a robustness test, we use (2 digit SIC) industry top and bottom quartiles of carbon intensity instead of the median to distinguish firms based on carbon efficiency. Results (available upon request) are qualitatively similar to the ones in Table 8 .
} 
Carbon cost pass through and carbon emission performance

$<<<$ Insert Table 8 here $>>>$ 


\section{Robustness test}

Following Larcker and Rusticus (2010), we investigate whether our results are sensitive to the instruments used. First, we use a different proxy for the stringency of the regulatory environment in which the firm operates by focusing on the countries' emissions-to-cap. For each phase, we measure the average allocation ratio per country. Countries with an over allocation of allowances are considered as having poor climate policy while countries with an under allocation of allowances are considered as pursuing stringent climate policy. Using this alternative stringency proxy, we find similar results.

In a second robustness check, we estimate the regressions with absolute carbon intensity lagged two years, $\triangle E T C$ and Stringency as the instruments. Carbon intensity lagged two periods may be more exogenous than carbon intensity lagged only one period. Our findings are not affected. Also $\triangle E T C$ lagged one year provides similar results. ${ }^{22}$

\section{Conclusions and implications}

In this study, we examine the impact of carbon cost pass through on the link between carbon emissions and corporate financial performance within the context of EU ETS. Using a sample of 368 listed firms over the period 2005-2012, we find in accordance with most of previous research that, overall, emission performance is positively related with economic performance. This result is in line with the view that stronger pollution is associated with financial risks caused by abatement, litigation, remediation and reputational costs, all of which combined may be considerable.

However, by making the distinction between firms that are able to pass through environmental costs and firms that are not, we show that the positive association between carbon emission performance (inversely measured by verified carbon emissions over sales) and CFP is not so straightforward. We demonstrate that superior emission performance is not rewarded if firms are able to pass through environmental costs either due to industry characteristics or firm specific carbon efficiency. These findings show that, while carbon inefficiency is associated with increasing environmental costs, this negative impact of relative carbon emission performance on economic performance is mitigated for firms that can pass on these costs to end users and/or customers. Overall, by explicitly considering industry or firm characteristics, we show that carbon efficiency not necessarily leads to better corporate financial performance. Our findings that carbon cost pass through and carbon efficiency

\footnotetext{
${ }^{22}$ Results for these various robustness tests are not reported for parsimonious reasons but available upon request.
} 
strongly influence the EP-CFP relationship, may contribute to explaining the conflicting results found in previous studies on this relationship.

Our results are both statistically and economically meaningful and hold after accounting for the endogeneity of a firm's carbon emission performance by using fixed effect instrumental variable models. The fact that the firms in our sample all operate installations covered by the EU ETS provides us with novel instruments of emission performance related to regulatory stringency at country level and firm specific emission allowances. This way, our study not only complements earlier studies on the endogenous relationship between corporate social responsibility and firm performance (e.g., Garcia-Castro et al., 2010) but it also provides empirical evidence concerning the effectiveness of a cap-and trade system with respect to carbon efficiency and the pass through of carbon related production costs.

The findings in this study also provide several implications for future empirical research in environmental economics as well as for policy makers concerned with environmental regulation. Empirical research on the relationship between carbon performance and economic performance has already uncovered many interesting insights on how differences in carbon efficiency among firms are related to firm value, profitability or other economic performance indicators. However, our results provide further evidence that in order to explore the true nature and causality of these relationships, several important issues must be addressed. First, as high operational performance could be positively related to financial as well as carbon efficiency, an empirical design should always control for potential endogeneity by employing instruments that drive carbon efficiency without directly influencing corporate financial performance. Second, the difference in the EP-CFP relationship depending on carbon leakage industries shows that sample (i.e., industry) selection can strongly influence the generalizability of results. Finally, it is important to take into account the initial level of carbon efficiency as this might alter the competitive position as well as the incentives from the mechanisms installed by environmental regulation. Addressing and controlling for these aspects might not only explain some of the inconsistencies among previous empirical results but could also be applied to studies that consider other aspects of environmental performance besides carbon emissions.

In terms of policy implications, our results show that, at least over the sample period, in case costs can be passed through due to industry characteristics, there are little financial incentives for firms to be green. This finding suggests that if regulatory tools like a cap-andtrade system imposes costs that can be passed through, firms will do so while the opportunity 
cost of this action not necessarily leads to emission reducing investments. Secondly, a simple output based emission trading scheme might not meet the expected climate goals even irrespective of industry characteristics. Firms within the industry that are already at a high level of carbon efficiency relative to competitors, might again not be incentivized to further improve carbon performance. Policy makers should try to complement the value based market mechanism of trading carbon allowances with a principle based mechanism (e.g., naming and shaming, mandatory emission announcements similar to earnings announcements) as literature shows that stakeholder perceptions about a firm's (green) reputation can also strongly influence financial performance. This kind of mechanism could incentivize the already carbon efficient firms to do even better and not just meet the mandatory emission allowances. Finally, results on the carbon leakage (no pass through) subsample exposes an important drawback of environmental policy mechanisms such as EU ETS in that they are usually locally binding for companies that are operating in globally competitive product markets (Dechezleprêtre and Sato, 2017). Differences in environmental regulatory stringency across countries can therefore cause a so called "pollution haven effect" where especially multinational business groups subject to strong regulation transfer pollution to host countries with weaker regulation (Dam and Scholtens, 2012; Kheder and Zugravu, 2012). To mitigate such problems, the logic from the literature concerning the importance of stakeholder pressure again suggests that regulators should enforce corporate transparency concerning pollution issues as this may strengthen stakeholder awareness and hence stakeholder pressure enforcing a positive relationship between carbon emission performance and financial performance for all firms regardless of industry or carbon efficiency. 


\section{Appendix Description of the variables}

\begin{tabular}{|c|c|}
\hline Variable & Description \\
\hline $\begin{array}{l}\text { Dependent } \\
\text { variables }\end{array}$ & \\
\hline Tobin’s Q & $\begin{array}{l}\text { (market value of equity + book value of debt) / (book value of equity } \\
+ \text { book value of debt). We measure equity market value the day after } \\
\text { the announcement of verified emissions to coincide with the date that } \\
\text { carbon emissions are disclosed. The Debt and Equity book value are } \\
\text { measured at the end of the fiscal year in which the verified emissions } \\
\text { are disclosed. Adjusted for industry and year effects by subtracting } \\
\text { the yearly industry median from the individual firms' Tobin's Q } \\
\text { value. }\end{array}$ \\
\hline
\end{tabular}

ROA

ROE

\section{Instrumented \\ variable}

EP

\section{Instruments \\ L.Intensity \\ Stringency}

$\triangle \mathrm{ETC}$

\section{Control variables}

Size

Growth

Leverage

CapInt
Net income + interest expenses/total assets. Adjusted for industry and year effects by subtracting the yearly industry median from the individual firms' ROA value.

Net income/book value of equity Adjusted for industry and year effects by subtracting the yearly industry median from the individual firms' ROE value.

Carbon emission performance is inversely measured as verified emissions divided by sales, minus the yearly industry median intensity. The firm's industrial affiliation is assessed on the two-digit SIC code.

Verified emissions divided by sales lagged one year.

Weighted-average of the regulatory stringency for all the countries in which the firm operates, based on NAPs

Yearly percentage change in emissions-to-cap ratio. The latter is calculated as the difference between verified and allocated emissions divided by allocated emissions.

The logarithm of the firm's total assets.

Yearly percentage change in sales

Long Term Debt + Short Term Debt \& Current Portion of Long Term Debt) / (Total Capital + Short Term Debt \& Current Portion of Long Term Debt) $* 100$

Capital expenditures divided by Total assets 


\section{References}

Abdallah T, Farhat A, Diabat A, Kennedy S. 2012. Green supply chains with carbon trading and environmental sourcing: Formulation and life cycle assessment. Applied Mathematical Modelling 36(9): 4271-4285. DOI: 10.1016/j.apm.2011.11.056

Aggarwal R, Dow S. 2012. Corporate governance and business strategies for climate change and environmental mitigation. The European Journal of Finance 18(3-4): 311-331. DOI: $10.1080 / 1351847 x .2011 .579745$

Alexeeva-Talebi V. 2011. Cost pass-through of the EU emissions allowances: Examining the European petroleum markets. Energy Economics 33: S75-S83. DOI: 10.1016/j.eneco.2011.07.029

Alvarez IG. 2012. Impact of CO2 emission variation on firm performance. Business Strategy and the Environment 21(7): 435-454. DOI: 10.1002/bse.1729

Ambec S, Lanoie P. 2008. Does it pay to be green? A systematic overview. Academy of Management Perspectives 22(4): 45-62. DOI: 10.5465/amp.2008.35590353

Barth ME, McNichols MF. 1994. Estimitation and market valuation of environmental liabilities relating to superfund sites. Journal of Accounting Research 32: 177-209. DOI: $10.2307 / 2491446$

Betz R, Sato M. 2006. Emission trading: Lesson learnt from the 1st phase of the EU ETS and prospects for the 2nd phase. Climate Policy 6(4): 351-359. DOI: 10.3763/cpol.2006.0624

Blass V, Corbett C, Delmas M, Muthulingam S. 2013. Top management and the adoption of energy efficiency practices: Evidence from small and medium-sized manufacturing firms in the US. Energy 65: 560-571. DOI: 10.1016/j.energy.2013.11.030

Busch T, Hoffmann V. 2011. How hot is your bottom line? Linking carbon and financial performance. Business and Society 50(2): 233-265. DOI: 10.1177/0007650311398780

Calel R, Dechezlepretre A. 2016. Environmental policy and directed technological change: evidence from the European carbon market. Review of economics and statistics 98(1): 173-191. DOI: $10.1162 /$ rest_a_00470

Carbon Disclosure Project. 2013. The Carbon Disclosure Project Homepage. https://www.cdp.net/en

Chan HS, Li S, Zhang F. 2013. Firm competitiveness and the European Union emissions trading scheme. Energy Policy 63: 1056-1064. DOI: 10.1016/j.enpol.2013.09.032

Chapple L, Clarkson PM, Gold DL. 2013. The cost of carbon: Capital market effects of the proposed emission trading scheme (ETS). Abacus 49(1): 1-33. DOI: 10.1111/abac. 12006

Clarkson PM, Li Y, Pinnuck M, Richardson G. 2014. The value relevance of greenhouse gas emissions under the European Union Carbon Emissions Trading Scheme. European Accounting review 24(3): 551-580. DOI: 10.1080/09638180.2014.927782

Clò S. 2010. Grandfathering, auctioning and Carbon Leakage: Assessing the inconsistencies of the new ETS Directive. Energy Policy 38(5): 2420-2430. DOI: 10.1016/j.enpol.2009.12.035

Connors E, Silva-Gao L. 2008. The impact of environmental risk on the cost of equity capital: evidence from the toxic release inventory, working paper.

Cordeiro JJ, Sarkis J. 1997. Environmental proactivism and firm performance: evidence from security analyst earnings forecasts. Business Strategy and the Environment 6(2): 104114. DOI: 10.1002/(sici)1099-0836(199705)6:2<104::aid-bse102>3.3.co;2-k 
Czerny A, Letmathe P. 2017. Eco-efficiency: GHG reduction related environmental and economic performance. The case of the companies participating in the EU Emissions Trading Scheme. Business Strategy and the Environment 26(6): 791-806. DOI: $10.1002 /$ bse. 1951

Dam L, Scholtens B. 2012. The curse of the haven, The impact of multinational enterprise on environmental regulation. Ecological Economics 78: 148-156. DOI: 10.1016/j.ecolecon.2012.04.011

Dechezleprêtre A, Sato M. 2017. The impacts of environmental regulations on competitiveness. Review of Environmental Economics and Policy 11(2): 183-206. DOI: $10.1093 /$ reep/rex013

Del Río González P. 2009. The empirical analysis of the determinants for environmental technological change: A research agenda. Ecological Economics 68(3): 861-878. DOI: 10.1016/j.ecolecon.2008.07.004

Delmas M, Etzion D, Nairn-Birch N. 2013. Triangulating environmental performance: What do corporate social responsibility ratings really capture? Academy of management perspectives 27(3): 255-267. DOI: 10.5465/amp.2012.0123

Delmas M, Nairn-Birch N, Lim J. 2015. Dynamics of environmental and financial performance: the case of greenhouse gas emissions. Organization and Environment 28(4): 374-393. DOI: $10.1177 / 1086026615620238$

Doh J, Howton SD, Howton SW, Siegel D. 2010. Does the market respond to an endorsement of social responsibility? The role of institutions, information and legitimacy. Journal of management. 36(6): 1461-1485. DOI: 10.1177/0149206309337896

Donaldson T, Preston L. 1995. The stakeholder theory of the corporation: concepts, evidence and implications. Academy of Management Review 20(1): 65-91. DOI: 10.3138/9781442673496-011

Endrikat J, Guenther E, Hoppe H. 2014. Making sense of conflicting empirical findings: a meta-analytic review of the relationship between corporate environmental and financial performance. European Management Journal 32(5): 735-751. DOI: 10.1016/j.emj.2013.12.004

Ernst and Young. 2009. Economics of Carbon.

European Commission, 2013. The EU Emission Trading System (EU ETS). Brussels

European Commission. 2009. Impact assessment accompanying the commission decision determining a list of sectors and subsectors which are deemed to be exposed to a significant risk of carbon leakage pursuant to Article 10a (13) of Directive 2003/87/ec.

European Commission. 2010. 2009/10251/EU: Commission decision of 24 December determining a list of sectors and subsectors which are deemed to a significant risk of carbon leakage. Brussels.

European Commission. 2011. 2011/745/EU:Commission decision of 11 November 2011 as regards the sectors and subsectors which are deemed to be exposed to a significant risk of carbon leakage. Brussels.

European Commission. 2012. 2012/498/EU: Commission decision of 17 August 2012 as regards the sectors and subsectors which are deemed to be exposed to a significant risk of carbon leakage. Brussels.

Fischer C, Fox AK. 2012. Comparing policies to combat emissions leakage: Border carbon adjustments versus rebates. Journal of Environmental Economics and Management 64(2): 199-216. DOI: 10.1016/j.jeem.2012.01.005

Frondel MH, Rennings JK. 2006. End-of-pipe or Cleaner Production? An Empirical Comparison of Environmental Innovation Decisions across OECD Countries. Business Strategy and the Environment 16(8): 571-584. DOI: 10.1002/bse.496 
Fujii H, Iwata K, Kaneko S, Managi S. 2013. Corporate environmental and economic performance of Japanese manufacturing firms: empirical study of sustainable development. Business Strategy and the environment 22(3): 187-201. DOI: $10.1002 /$ bse. 1747

Gallego-Alvarez I, Garcia-Sanchez I, de Silva Vieira C, 2014, Climate change and financial performance in times of crisis, Business Strategy and the environment 23(6): 361-374. DOI: $10.1002 /$ bse. 1786

Garcia-Castro R, Ariño MA, Canela MA. 2010. Does social performance really lead to financial performance? Accounting for endogeneity. Journal of Business Ethics 92(1): 107-126. DOI: $10.1007 / \mathrm{s} 10551-009-0143-8$

Gilbert A, Bode J, Phylipsen D. 2004. Analysis of the national allocation plans for the EU emissions trading scheme. ECOFYS, London.

Grubb M, Azar C, Persson UM. 2005. Allowance allocation in the European emissions trading system: a commentary. Climate Policy 5(1): 127-136. DOI: 10.3763/cpol.2005.0502

Grubb M, Brewer TL, Sato M, Heilmayr R, Fazekas D. 2009. Climate policy and industrial competitiveness. Ten insights from Europe on the EU emissions trading system. Washington, DC: German Marshall Fund of the United States.

Hart SL, Ahuja G. 1996. Does it pay to be green? An empirical examination of the relationship between emission reduction and firm performance. Business Strategy and the Environment 5(1): 30-37. DOI: 10.1002/(sici)1099-0836(199603)5:1<30::aidbse $38>3.0 . c 0 ; 2-q$

Hausman J. 1978. Specification tests in econometrics. Econometrica 46: 1251-1271.

Hughes II, Reynolds JK. 2001. Uncertainty Associated with Future Environmental Costs and the Market's Differential Response to Earnings Information. Journal of Business Finance \& Accounting 28(9-10): 1351-1386. DOI: 10.1111/1468-5957.00418

Jong T, Couwenberg O, Woerdman E. 2014. Does EU emissions trading bite? An event study. Energy Policy 69: 510-519. DOI: 10.1016/j.enpol.2014.03.007

Kesidou E, Demirel P. 2012. On the drivers of eco-innovations: empirical evidence from the UK. Research Policy 41(5): 862-870. DOI: 10.1016/j.respol.2012.01.005

Kheder S. B., Zugravu N., 2012. Environmental regulation and French firms location abroad, An economic geography model in an international comparative study. Ecological Economics 77, 48-61.

King A, Lenox M. 2001. Does it really pay to be green. The Journal of Industrial Ecology 5(1): 105-116. DOI: 10.1162/108819801753358526

Kneller R, Manderson E. 2012. Environmental regulations and innovation activity in UK manufacturing industries. Resource and Energy Economics 34(2): 211-235. DOI: 10.1016/j.reseneeco.2011.12.001

Konar S, Cohen MA. 2001. Does the market value environmental performance. The Review of Economics and Statistics 83(2): 281-289. DOI: 10.1162/00346530151143815

Lannelongue G, Gonzalez-Benito J, Gonzalez-Benito O. 2015. Input, output, and environmental management productivity: effects on firm performance. Business Strategy and the Environment 24(3): 145-158. DOI: 10.1002/bse.1806

Larcker DF, Rusticus TO. 2010. On the use of instrumental variables in accounting research. Journal of Accounting and Economics 49(3): 186-205. DOI: 10.1016/j.jacceco.2009.11.004

Lise W, Sijm J, Hobbs BF. 2010. The impact of the EU ETS on prices, profits and emissions in the power sector: simulation results with the COMPETES EU20 model. 
Environmental and Resource Economics 47(1): 23-44. DOI: 10.1007/s10640-0109362-9

Little IM. 1962. Higgledy piggledy growth. Bulletin of the Oxford University Institute of Economics \& Statistics 24(4): 387-412. DOI: $10.1111 / \mathrm{j} .1468-$ 0084.1962.mp24004001.X

Matisoff D, Noonan S, O'Brien J. 2013. Convergence in environmental reporting: assessing the carbon disclosure project. Business Strategy and the environment 22(5): 285-305. DOI: $10.1002 /$ bse. 1741

Matsumura EM, Prakash R, Vera-Muñoz SC. 2014. Firm-value effects of carbon emissions and carbon disclosures. The Accounting Review 89(2): 695-724. DOI: 10.2308/accr50629

Misani N, Pogutz S, Russo A. 2012. Investigating the relationship between firm carbon intensity and financial performance: the role of organizational responsiveness. In Conference Paper, Università Bocconi [online][25 Apr 2014]. Available from Internet URL: http://www.gronen2012.org.

Nishitani K, Kokubu K. 2012. Why does the reduction of greenhouse gas emissions enhance firm value? The case of Japanese manufacturing firms. Business Strategy and the Environment 21(8): 517-529. DOI: $10.1002 /$ bse. 734

Oberndorfer U. 2009. EU emission allowances and the stock market: evidence from the electricity industry. Ecological Economics 68(4): 1116-1126. DOI: 10.1016/j.ecolecon.2008.07.026

Porter M, van der Linde C. 1995. Toward a new conception of the environmentcompetitiveness relationship. Journal of Economic Perspectives 9(4): 97-118. DOI: 10.1257/jep.9.4.97

Rayner AC, Little IMD. 1966. Higgledy piggledy growth again: an investigation of the predictability of company earnings and dividends in the UK, 1951-1961. Blackwell.

Renders A, Gaeremynck A, Sercu P. 2010. Corporate-governance ratings and company performance: A cross-European study. Corporate Governance: An international Review 18(2): 87-106. DOI: 10.1111/j.1467-8683.2010.00791.x

Rennings K, Ziegler A, Ankele K, Hoffmann E. 2006. The influence of different characteristics of the EU environmental management and auditing scheme on technical environmental innovations and economic performance. Ecological Economics 57(1): 45-59. DOI: 10.1016/j.ecolecon.2005.03.013

Saka C, Oshika T. 2014. Disclosure effects, carbon emissions and corporate value. Sustainability Accounting, Management and Policy Journal 5(1): 22-45. DOI: 10.1108/sampj-09-2012-0030

Sariannidis N, Zafeiriou E, Giannarakis G, Arabatzis G. 2013. CO2 emissions and financial performance of socially responsible firms: an empirical survey. Business Strategy and the Environment 22(2): 109-120. DOI: 10.1002/bse.1737

Schmidt RC, Heitzig J. 2014. Carbon leakage: Grandfathering as an incentive device to avert firm relocation. Journal of Environmental Economics and Management 67(2): 209223. DOI: $10.1016 /$ j.jeem.2013.12.004

Schreck P. 2011. Reviewing the business case for corporate social responsibility: New evidence and analysis. Journal of Business Ethics 103(2): 167-188. DOI: 10.1007/s10551-011-0867-0

Semadeni M, Withers MC, Trevis Certo S. 2014. The perils of endogeneity and instrumental variables in strategy research: Understanding through simulations. Strategic Management Journal 35(7): 1070-1079. DOI: 10.1002/smj.2136 
Shrivastava, P ,1995, Environmental technologies and competitive advantage, Strategic management journal, 16, 183-200.

Sijm J, Neuhoff K, Chen Y. 2006. Cost pass-through and windfall profits in the power sector. Climate Policy 6(1): 49-72. DOI: 10.3763/cpol.2006.0604

Stanwick PA, Stanwick SD. 1998. The relationship between corporate social performance, and organizational size, financial performance, and environmental performance: An empirical examination. Journal of business ethics 17(2): 195-204. DOI: 10.1023/a:1005784421547

Stock J, Yogo M. 2004. Testing for weak instruments in linear IV Regression. In D. W. K. Andrews \& J. H. Stock (Eds.), Identification and inference for econometric models: Essays in honor of Thomas J. Rothenberg. Cambridge: Cambridge University Press

Trumpp C, Guenther T. 2017. Too Little or too much? Exploring U-shaped Relationships between Corporate Environmental Performance and Corporate Financial Performance. Business Strategy and the Environment 26(1): 49-68. DOI: 10.1002/bse.1900

Veith S, Werner JR, Zimmermann J. 2009. Capital market response to emission rights returns: Evidence from the European power sector. Energy Economics 31(4): 605-613. DOI: 10.1016/j.eneco.2009.01.004

Venmans F. 2012. A literature-based multi-criteria evaluation of the EU ETS. Renewable and Sustainable Energy Reviews 16(8): 5493-5510. DOI: 10.1016/j.rser.2012.05.036

Venmans F. 2015. Capital market response to emission allowance prices: a multivariate GARCH approach. Environmental Economics and Policy Studies 17(4): 577-620. DOI: $10.1007 / \mathrm{s} 10018-015-0105-6$

Wahba H. 2008. Does the market value corporate environmental responsibility? An empirical examination. Corporate Social Responsibility and Environmental Management 15(2): 89-99. DOI: $10.1002 / \mathrm{csr} .153$

Wang CJ. 2015. Instrumental variables approach to correct for endogeneity in finance. In Handbook of Financial Econometrics and Statistics (pp. 2577-2600). Springer New York.

Wang L, Li S, Gao S. 2014. Do greenhouse gas emissions affect financial performance?-an empirical examination of Australian public firms. Business Strategy and the Environment 23(8): 505-519. DOI: 10.1002/bse.1790

Weesie J. 1999. Seemingly unrelated regression and the cluster-adjusted sandwich estimator. STATA Technical Bulletin 52: 34-46. 
Table 1 Environmental regulation stringency across EU ETS countries and phases

\begin{tabular}{|c|c|c|c|c|c|}
\hline Country & $\begin{array}{c}\text { Phase } \\
\text { I }\end{array}$ & $\begin{array}{c}\text { Phase } \\
\text { II }\end{array}$ & Country & $\begin{array}{c}\text { Phase } \\
\text { I }\end{array}$ & $\begin{array}{c}\text { Phase } \\
\text { II }\end{array}$ \\
\hline Austria & 0 & 1 & Latvia & 0 & 0 \\
\hline Belgium & 1 & 0 & Liechtenstein & - & - \\
\hline Bulgaria & - & - & Lithuania & 1 & 0 \\
\hline Cyprus & - & 1 & Luxembourg & 0 & 1 \\
\hline Czech Republic & 0 & 0 & Malta & - & 0 \\
\hline Denmark & 0 & 1 & Netherlands & 0 & 1 \\
\hline Estonia & 0 & 1 & Norway & - & - \\
\hline Finland & 0 & 0 & Poland & 0 & 1 \\
\hline France & 0 & 1 & Portugal & 0 & 0 \\
\hline Germany & 1 & 1 & Romania & - & - \\
\hline Greece & 0 & 1 & Slovakia & 0 & 0 \\
\hline Hungary & 1 & 1 & Slovenia & 0 & 1 \\
\hline Iceland & - & - & Spain & 0 & 1 \\
\hline Ireland & 0 & 1 & Sweden & 0 & 0 \\
\hline Italy & 0 & 1 & UK & 1 & 1 \\
\hline
\end{tabular}

This table reports the environmental stringency of countries with installations covered by the ETS. The environmental stringency is based on the National Allocation Plans (NAPs). Stringent Naps for the first phase are plans with fewer allowances allocated than national Kyoto targets ((Gilbert et al., 2004; Grubb et al., 2005). Stringent NAPs for the second phase are plans with fewer allowances allocated compared to the 2005 verified emissions (Betz et al., 2006). " 1 " stands for stringent, " 0 " for non-stringent and "-" indicates that the stringency of the NAPs could not be determined. ${ }^{23}$

\footnotetext{
${ }^{23}$ Bulgaria, Romania, Norway, Iceland, Liechtenstein joined the ETS in the second phase
} 
Table 2 EU ETS installation across EU ETS countries

\begin{tabular}{|c|c|c|c|c|c|c|}
\hline Country & $\begin{array}{l}\text { Listed } \\
\text { Firms } \\
\end{array}$ & $\%$ & $\begin{array}{c}\text { Installations } \\
\text { Sample }\end{array}$ & $\%$ & $\begin{array}{c}\text { Installations } \\
\text { EU ETS }\end{array}$ & $\%$ \\
\hline Austria & 8 & $2.17 \%$ & 72 & $2.04 \%$ & 228 & $1.75 \%$ \\
\hline Belgium & 12 & $3.26 \%$ & 163 & $4.61 \%$ & 367 & $2.82 \%$ \\
\hline Bulgaria & 8 & $2.17 \%$ & 29 & $0.82 \%$ & 151 & $1.16 \%$ \\
\hline Cyprus & 0 & $0.00 \%$ & 0 & $0.00 \%$ & 13 & $0.10 \%$ \\
\hline Czech Republic & 7 & $1.90 \%$ & 139 & $3.93 \%$ & 427 & $3.29 \%$ \\
\hline Denmark & 9 & $2.45 \%$ & 54 & $1.53 \%$ & 409 & $3.15 \%$ \\
\hline Estonia & 0 & $0.00 \%$ & 19 & $0.54 \%$ & 58 & $0.45 \%$ \\
\hline Finland & 13 & $3.53 \%$ & 126 & $3.57 \%$ & 662 & $5.09 \%$ \\
\hline France & 41 & $11.14 \%$ & 382 & $10.81 \%$ & 1130 & $8.69 \%$ \\
\hline Germany & 54 & $14.67 \%$ & 604 & $17.10 \%$ & 2012 & $15.48 \%$ \\
\hline Greece & 7 & $1.90 \%$ & 55 & $1.56 \%$ & 164 & $1.26 \%$ \\
\hline Hungary & 5 & $1.36 \%$ & 67 & $1.90 \%$ & 274 & $2.11 \%$ \\
\hline Iceland & 0 & $0.00 \%$ & 1 & $0.03 \%$ & 4 & $0.03 \%$ \\
\hline Ireland & 5 & $1.36 \%$ & 26 & $0.74 \%$ & 125 & $0.96 \%$ \\
\hline Italia & 28 & $7.61 \%$ & 352 & $9.96 \%$ & 1215 & $9.35 \%$ \\
\hline Latvia & 4 & $1.09 \%$ & 9 & $0.25 \%$ & 111 & $0.85 \%$ \\
\hline Liechtenstein & 0 & $0.00 \%$ & 0 & $0.00 \%$ & 2 & $0.02 \%$ \\
\hline Lithuania & 10 & $2.72 \%$ & 26 & $0.74 \%$ & 114 & $0.88 \%$ \\
\hline Luxembourg & 1 & $0.27 \%$ & 6 & $0.17 \%$ & 15 & $0.12 \%$ \\
\hline Malta & 0 & $0.00 \%$ & 0 & $0.00 \%$ & 2 & $0.02 \%$ \\
\hline Netherlands & 12 & $3.26 \%$ & 134 & $3.79 \%$ & 448 & $3.45 \%$ \\
\hline Norway & 5 & $1.36 \%$ & 55 & $1.56 \%$ & 121 & $0.93 \%$ \\
\hline Poland & 17 & $4.62 \%$ & 184 & $5.21 \%$ & 943 & $7.25 \%$ \\
\hline Portugal & 8 & $2.17 \%$ & 48 & $1.36 \%$ & 284 & $2.18 \%$ \\
\hline Romania & 10 & $2.72 \%$ & 56 & $1.59 \%$ & 280 & $2.15 \%$ \\
\hline Slovakia & 8 & $2.17 \%$ & 10 & $0.28 \%$ & 203 & $1.56 \%$ \\
\hline Slovenia & 6 & $1.63 \%$ & 49 & $1.39 \%$ & 100 & $0.77 \%$ \\
\hline Spain & 23 & $6.25 \%$ & 316 & $8.94 \%$ & 1154 & $8.88 \%$ \\
\hline Sweden & 16 & $4.35 \%$ & 107 & $3.03 \%$ & 834 & $6.42 \%$ \\
\hline UK & 51 & $13.86 \%$ & 444 & $12.57 \%$ & 1148 & $8.83 \%$ \\
\hline TOTAL & 368 & $100 \%$ & 3533 & $100 \%$ & 12998 & $100 \%$ \\
\hline
\end{tabular}

This table reports the distribution of 368 listed firms with installations covered by the EU ETS across countries comparing sample with population based on data provided by Carbon Market Data 
Table 3 Univariate statistics and tests

\begin{tabular}{|c|c|c|c|c|c|c|c|c|}
\hline & \multicolumn{2}{|c|}{ Full sample } & \multicolumn{2}{|c|}{ Pass-Through } & \multicolumn{2}{|c|}{ No Pass-Through } & \multicolumn{2}{|c|}{ Difference tests } \\
\hline & Mean & Median & Mean & Median & Mean & Median & Mean & Median \\
\hline \multicolumn{9}{|c|}{ Performance variables } \\
\hline Tobin's Q & 1.331 & 1.175 & 1.352 & 1.186 & 1.310 & 1.166 & $1.918^{* * *}$ & $1.702 *$ \\
\hline ROA & 4.929 & 4.835 & 5.001 & 4.845 & 4.826 & 4.795 & 0.632 & 0.590 \\
\hline ROE & 10.053 & 10.732 & 11.089 & 11.325 & 9.328 & 9.99 & $1.940 *$ & $1.702 *$ \\
\hline \multicolumn{9}{|c|}{ Instrumented variable } \\
\hline EP & -0.110 & 0 & -0.530 & -.157 & 0.176 & .088 & $-8.085 * * *$ & $-6.490 * * *$ \\
\hline \multicolumn{9}{|c|}{ Instruments } \\
\hline Intensity & -2.666 & -2.386 & -2.879 & -2.792 & -2.520 & -1.966 & $-3.343 * * *$ & $-3.542 * * *$ \\
\hline Stringency & 0.500 & 0.516 & 0.532 & 0.621 & 0.474 & 0.452 & $3.144 * * *$ & $4.162 * * *$ \\
\hline$\Delta \mathrm{ETC}$ & -0.327 & -0.083 & -0.275 & -0.083 & -0.368 & -0.081 & $-1.702 *$ & -1.140 \\
\hline \multicolumn{9}{|c|}{ Control variables } \\
\hline Size & 14.654 & 14.817 & 14.587 & 14.869 & 14.700 & 14.837 & -1.236 & -0.928 \\
\hline Growth & 0.080 & 0.065 & 0.084 & 0.060 & 0.076 & 0.066 & 0.806 & 0.220 \\
\hline Leverage & 38.365 & 38.060 & 42.646 & 43.880 & 35.319 & 35.120 & $8.792 * * *$ & $9.519 * * *$ \\
\hline Caplnt & 0.078 & 0.052 & 0.087 & 0.055 & 0.072 & 0.051 & $4.682 * * *$ & $2.285^{* *}$ \\
\hline
\end{tabular}

This table compares the means and medians of the variables of the pass-through sample with those of the no pass-through sample. Whether or not a firm is able to pass through pollution costs is based on the information provided in three Commission decisions (European Commission, 2010; 2011; 2012). Two tailed T-tests for the mean and Wilcoxon ranksum test statistics for the median are presented. $* * *, * *, *$ denote significance at the $1 \%, 5 \%$ and $10 \%$ level. 
Table 4 Pearson correlations on subsamples of carbon pass through costing

\begin{tabular}{|c|c|c|c|c|c|c|c|c|c|c|c|}
\hline & 1 & 2 & 3 & 4 & 5 & 6 & 7 & 8 & 9 & 10 & 11 \\
\hline 1.Tobin's Q & 1 & $\underset{\substack{0.438 \\
* * *}}{0.438}$ & $\underset{* * *}{0.331}$ & $\underset{*}{-0.051}$ & $-\underset{* *}{-0.085}$ & 0.020 & -0.017 & $\underset{* * \star}{0.112}$ & $\underset{* *}{0.064}$ & 0.047 & -0.001 \\
\hline 2.ROA & $\underset{* * *}{0.266}$ & 1 & $\underset{* * *}{0.767}$ & $\underset{*}{-0.060}$ & $\underset{* *}{-0.078}$ & -0.032 & -0.021 & $\underset{* * *}{0.199}$ & $\underset{* * *}{0.080}$ & $\underset{* \star}{-0.076}$ & 0.001 \\
\hline 3.ROE & $\underset{* * *}{0.255}$ & $\underset{* * *}{0.835}$ & 1 & -0.030 & $\begin{array}{c}-0.060 \\
*\end{array}$ & -0.015 & -0.021 & $\underset{* * *}{0.222}$ & $\underset{* * *}{0.085}$ & $\underset{* *}{0.059}$ & 0.040 \\
\hline 4.EP & $\underset{* * *}{-0.128}$ & $-\underset{* * *}{-0.141}$ & $\underset{* \star *}{-0.142}$ & 1 & $\underset{* * *}{0.702}$ & $-\underset{* * *}{0.173}$ & $\underset{* *}{0.080}$ & $\underset{* * *}{-0.342}$ & 0.043 & $\underset{* * *}{-0.217}$ & -0.053 \\
\hline 5.L.Intensity & -0.109 & -0.074 & $-\underset{* * *}{-0.092}$ & $\underset{* * *}{0.658}$ & 1 & $-\underset{* * *}{-0.173}$ & 0.001 & $\underset{* * \star}{-0.187}$ & $\underset{* *}{0.083}$ & $\underset{* *}{-0.161}$ & $\underset{* * *}{0.252}$ \\
\hline 6.Stringency & $\underset{*}{0.054}$ & $\underset{*}{0.052}$ & 0.026 & $\underset{\star * *}{-0.074}$ & $\underset{* * *}{-0.111}$ & 1 & -0.051 & $\underset{* * \star}{0.226}$ & -0.002 & $\underset{* * *}{0.195}$ & $\underset{* *}{-0.081}$ \\
\hline 7. $\triangle \mathrm{ETC}$ & 0.018 & 0.257 & 0.041 & $\underset{*}{0.053}$ & -0.016 & -0.026 & 1 & -0.030 & $\underset{* * *}{0.144}$ & -0.027 & -0.010 \\
\hline 8.Size & $\underset{* * *}{0.075}$ & $\underset{*}{0.056}$ & $\underset{\star \star \star \star}{0.093}$ & $\underset{* * *}{-0.386}$ & $\underset{* \star *}{-0.472}$ & $\underset{* * *}{0.261}$ & & 1 & $\underset{* \star *}{0.081}$ & $\underset{* \star *}{0.378}$ & $\underset{* * *}{0.163}$ \\
\hline 9.Growth & $\underset{* *}{0.063}$ & $\underset{* * *}{0.074}$ & $\underset{* *}{0.063}$ & -0.015 & 0.042 & -0.035 & $\underset{* * \star}{0.146}$ & 0.017 & 1 & 0.021 & $\underset{* *}{0.060}$ \\
\hline 10.Leverage & $\underset{* *}{-0.059}$ & $-\underset{* * *}{0.115}$ & $\underset{*}{-0.008}$ & -0.005 & $\underset{* *}{-0.070}$ & 0.029 & -0.019 & $0.190^{* * *}$ & -0.025 & 1 & $\underset{* * *}{0.192}$ \\
\hline 11.CapInt & 0.009 & 0.034 & -0.021 & $\underset{* *}{0.060}$ & $\underset{* * *}{0.161}$ & $\underset{* *}{0.061}$ & -0.006 & -0.002 & $\underset{* * *}{0.083}$ & -0.011 & 1 \\
\hline
\end{tabular}

This table reports the Pearson correlation coefficients for the continuous variables. P-values reported between brackets. $* * *, * *, *$ denote significance at the $1 \%, 5 \%$ and $10 \%$ level. The correlations for the firms able to pass through pollution costs using industry characteristics are reported at the upper right side and correlations for the firms not able to pass through pollution costs are reported at the lower left side. 
Table 5 Endogeneity test of the environmental-corporate performance relationship

\begin{tabular}{lccc}
\hline & TOBIN's Q & ROA & ROE \\
\hline HAUSMAN test & $40.66^{* * *}$ & $93.71^{* * *}$ & $55.75^{* * *}$ \\
p-value & 0.000 & 0.000 & 0.000 \\
\hline \multicolumn{4}{c}{ Results of Hausman test of endogeneity (chi squared) } \\
$* * *, * *, *$ denote significance at the $1 \%, 5 \%$ and $10 \%$ level.
\end{tabular}

Table 6 First-stage instrumental variables (FE-IV) estimation

\begin{tabular}{cccc}
\hline & Full sample & Pass & No Pass \\
\hline L.Intensity & $0.639^{* * *}$ & $0.629^{* * *}$ & $0.675^{* * *}$ \\
& $(0.000)$ & $(0.005)$ & $(0.000)$ \\
Stringency & $-0.147^{*}$ & $-0.126^{*}$ & -0.032 \\
& $(0.092)$ & $(0.064)$ & $(0.309)$ \\
$\Delta$ ETC & $0.046^{* *}$ & $0.049^{* * *}$ & $0.045^{* * *}$ \\
& $(0.000)$ & $(0.000)$ & $(0.002)$ \\
Size & $-0.197^{* *}$ & -0.145 & $-0.200^{*}$ \\
& $(0.014)$ & $(0.147)$ & $(0.084)$ \\
Growth & $-0.478^{* * *}$ & $-0.540^{* * *}$ & $-0.502^{* * *}$ \\
& $(0.000)$ & $(0.000)$ & $(0.000)$ \\
Leverage & $0.003^{*}$ & 0.002 & $0.003^{* *}$ \\
& $(0.003)$ & $(0.146)$ & $(0.031)$ \\
Caplnt & 0.220 & -0.025 & 0.356 \\
& $(0.394)$ & $(0.909)$ & $(0.440)$ \\
Firm-FE & Yes & Yes & Yes \\
Year-FE & Yes & Yes & Yes \\
& & & \\
Partial $\mathrm{R}^{2}$ & 45.69 & 49.33 & 47.14 \\
F-statistic & $286.24 * * *$ & $183.504 * * *$ & $109.09 * * *$ \\
Obs. & 2031 & 787 & 1189 \\
\hline
\end{tabular}

Whether or not a firm is able to pass through pollution costs is based on the information provided in three Commission decisions (European Commission, 2010; 2011; 2012). We report the coefficients, the Partial $\mathrm{R}^{2}$, the F-statistic and $\mathrm{p}$-values (between brackets) $* * *, * * *$ denote significance at the $1 \%, 5 \%$ and $10 \%$ level. 
Table 7 Second-stage instrumental variables (FE-IV) estimation (GMM) based on industry specific pass through costing

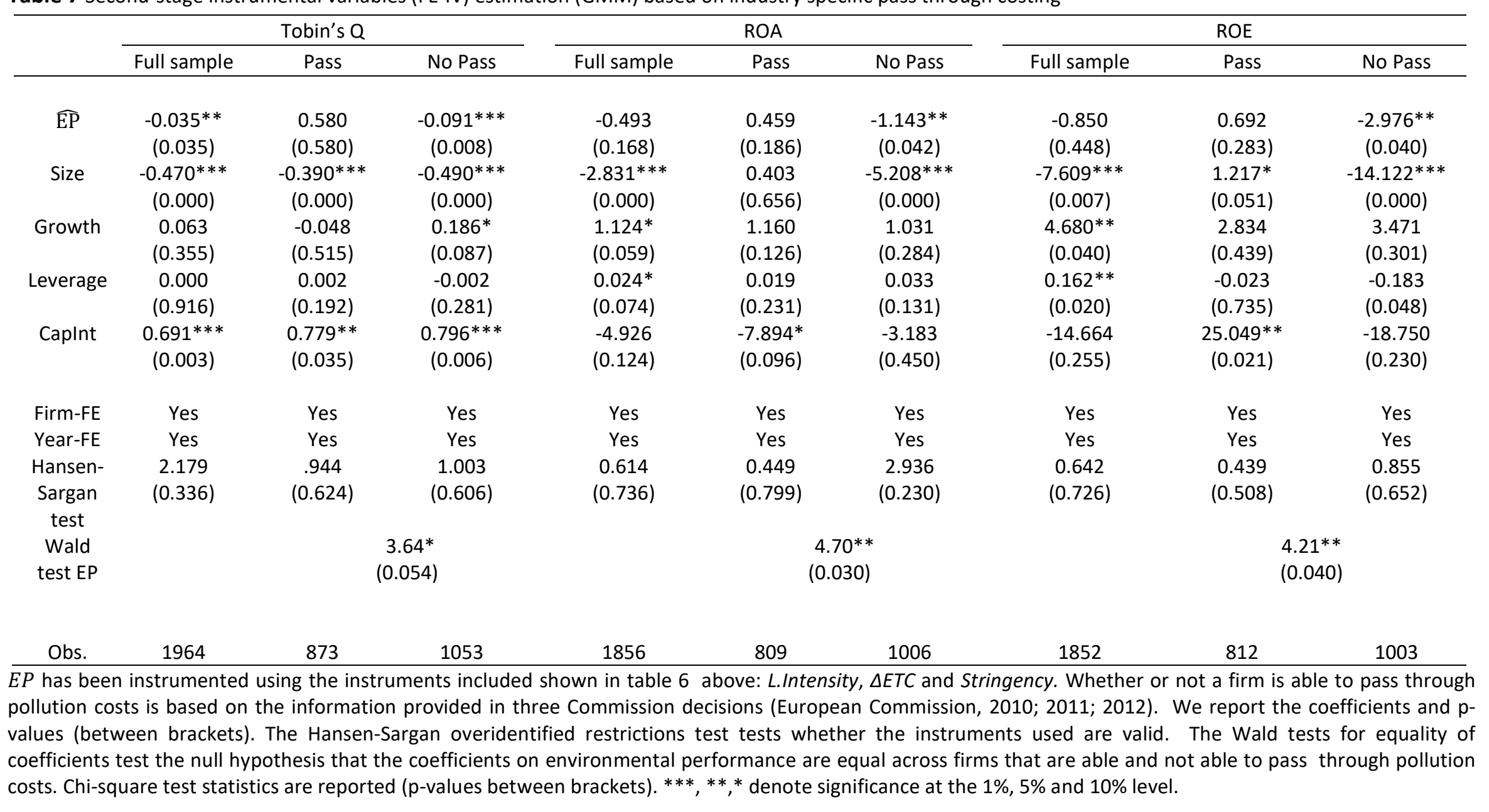


Table 8 Second-stage instrumental variables (FE-IV) estimation (GMM) based on firms specific pass through costing

\begin{tabular}{|c|c|c|c|c|c|c|}
\hline & \multicolumn{2}{|c|}{ Tobin's Q } & \multicolumn{2}{|c|}{ ROA } & \multicolumn{2}{|c|}{ ROE } \\
\hline & Pass & No Pass & Pass & No Pass & Pass & No Pass \\
\hline \multirow[t]{2}{*}{$\widehat{E P}$} & 0.018 & $-0.152 * *$ & 0.738 & $-4.410^{*}$ & 2.256 & $-13.030 *$ \\
\hline & $(0.601)$ & $(0.046)$ & $(0.157)$ & $(0.066)$ & $(0.317)$ & $(0.086)$ \\
\hline \multirow[t]{2}{*}{ Size } & $-0.584 * * *$ & $-0.397 * * *$ & $-2.833 * * *$ & $-3.856 * * *$ & $-9.298 * *$ & $-8.777^{*}$ \\
\hline & $(0.000)$ & $(0.000)$ & $(0.000)$ & $(0.005)$ & $(0.047)$ & $(0.083)$ \\
\hline \multirow[t]{2}{*}{ Growth } & -0.026 & 0.093 & 0.488 & 0.654 & 0.705 & 4.625 \\
\hline & $(0.818)$ & $(0.436)$ & $(0.528)$ & $(0.462)$ & $(0.821)$ & $(0.163)$ \\
\hline \multirow[t]{2}{*}{ Leverage } & 0.000 & 0.001 & 0.029 & $0.011 * * *$ & $0.246 * *$ & 0.118 \\
\hline & $(0.917)$ & $(0.443)$ & $(0.113)$ & $(0.543)$ & $(0.035)$ & $(0.257)$ \\
\hline \multirow[t]{2}{*}{ Caplnt } & $0.704 * * *$ & $0.661 * *$ & $-7.282^{*}$ & -1.737 & $-25.349 * *$ & -8.453 \\
\hline & $(0.076)$ & $(0.036)$ & $(0.085)$ & $(0.000)$ & $(0.043)$ & $(0.655)$ \\
\hline Firm-FE & Yes & Yes & Yes & Yes & Yes & Yes \\
\hline Year-FE & Yes & Yes & Yes & Yes & Yes & Yes \\
\hline \multirow[t]{2}{*}{ Hansen-Sargan test } & 2.871 & 4.071 & 2.914 & 0.192 & 2.503 & 0.464 \\
\hline & $(0.238)$ & (0.131) & $(0.233)$ & $(0.908)$ & $(0.286)$ & $(0.793)$ \\
\hline \multirow[t]{2}{*}{ Wald test EP } & \multicolumn{2}{|c|}{$2.88^{*}$} & \multicolumn{2}{|c|}{$3.89 * *$} & \multicolumn{2}{|c|}{$2.88^{*}$} \\
\hline & \multicolumn{2}{|c|}{$(0.089)$} & \multicolumn{2}{|c|}{$(0.048)$} & \multicolumn{2}{|c|}{$(0.089)$} \\
\hline Obs. & 935 & 941 & 900 & 865 & 899 & 860 \\
\hline
\end{tabular}

Second-stage instrumental variables (FE-IV) estimation (GMM) Whether or not a firm is able to pass through pollution costs is based on the median EP. Standard errors heteroscedasticity robust. We report the coefficients and $p$-values (between brackets). The Hansen-Sargan overidentified restrictions test tests whether the instruments used are valid ( $\mathrm{HO})$. The Wald tests for equality of coefficients test the null hypothesis that the coefficients on environmental performance are equal across firms that are able and not able to pass through carbon costs. Chi-square test statistics are reported (P-values between brackets). ${ }^{* * *},{ }^{* *},{ }^{*}$ denote significance at the $1 \%, 5 \%$ and $10 \%$ level 